OPEN ACCESS

Edited by:

Gertraud Orend,

INSERM Immuno Rhumatologie

Moléculaire (IRM), France

Reviewed by:

Marcus Franz,

University Hospital Jena, Germany

Hiromi Yanagisawa,

University of Tsukuba, Japan

Hidenori Suzuki,

Mie University, Japan

*Correspondence:

Ken-ichi Matsumoto

matumoto@med.shimane-u.ac.jp

Hiroki Aok

haoki@med.kurume-u.ac.jp

Specialty section:

This article was submitted to

Inflammation,

a section of the journal

Frontiers in Immunology

Received: 24 September 2020

Accepted: 03 November 2020

Published: 01 December 2020

Citation:

Matsumoto K-i and Aoki H (2020) The

Roles of Tenascins in Cardiovascular, Inflammatory, and Heritable

Connective Tissue Diseases.

Front. Immunol. 11:609752.

doi: 10.3389/fimmu.2020.609752

\section{The Roles of Tenascins in Cardiovascular, Inflammatory, and Heritable Connective Tissue Diseases}

\author{
Ken-ichi Matsumoto ${ }^{1 *}$ and Hiroki Aoki ${ }^{2 *}$ \\ ${ }_{1}^{1}$ Department of Biosignaling and Radioisotope Experiment, Interdisciplinary Center for Science Research, Organization for \\ Research and Academic Information, Shimane University, Izumo, Japan, ${ }^{2}$ Cardiovascular Research Institute, Kurume \\ University, Kurume, Japan
}

Tenascins are a family of multifunctional extracellular matrix (ECM) glycoproteins with timeand tissue specific expression patterns during development, tissue homeostasis, and diseases. There are four family members (tenascin-C, $-\mathrm{R},-\mathrm{X},-\mathrm{W}$ ) in vertebrates. Among them, tenascin-X (TNX) and tenascin-C (TNC) play important roles in human pathologies. TNX is expressed widely in loose connective tissues. TNX contributes to the stability and maintenance of the collagen network, and its absence causes classical-like Ehlers-Danlos syndrome (cIEDS), a heritable connective tissue disorder. In contrast, TNC is specifically and transiently expressed upon pathological conditions such as inflammation, fibrosis, and cancer. There is growing evidence that TNC is involved in inflammatory processes with proinflammatory or anti-inflammatory activity in a context-dependent manner. In this review, we summarize the roles of these two tenascins, TNX and TNC, in cardiovascular and inflammatory diseases and in CIEDS, and we discuss the functional consequences of the expression of these tenascins for tissue homeostasis.

Keywords: tenascin-C, tenascin-X, cardiovascular disease, fibrosis, inflammation, Ehlers-Danlos syndrome

\section{INTRODUCTION}

An important component of the extracellular environment is the extracellular matrix (ECM), which is comprised of glycoproteins, proteoglycans, and fibrillar proteins. The ECM offers not only structural support for cells but also influences cell adhesion, proliferation, differentiation, and survival through specific receptor-mediated interactions (1). Within the ECM, the tenascins comprise an attractive glycoprotein family with distinct features for each member.

\footnotetext{
Abbreviations: BDNF, brain-derived neurotrophic factor; BNP, B-type natriuretic peptide; circRNA, circular RNA; clEDS, classical-like Ehlers-Danlos syndrome; CNS, central nervous system; DRG, dorsal root ganglion; ECM, extracellular matrix; EDS, Ehlers-Danlos syndrome; EGF, epidermal growth factor; EMT, epithelial-mesenchymal transition; FBG, fibrinogen; FGFs, fibroblast growth factors; FNIII, fibronectin type III; HFCD, high levels of phosphorus and calcium; HFpEF, heart failure with preserved ejection fraction; IncRNA, long non-coding RNA; MMPs, matrix metalloproteinases; PDGFs, platelet-derived growth factors; PNS, peripheral nervous system; SLE, systemic lupus erythematosus; SNPs, single nucleotide polymorphisms; sTNX, serum form of TNX; TGF- $\beta$, transforming growth factor- $\beta$; TLR4, Toll-like receptor 4 ; TNC, tenascin-C; TNR, tenascin-R; TNW, tenascin-W; TNX, tenascin-X; Tnxb, mouse tenascin-X gene; TNXB, human tenascin-X gene; TNY, tenascin-Y; VEGF-B, vascular endothelial growth factor, B; VEGFR-1, vascular endothelial growth factor receptor 1; VUR, vesicoureteral reflux.
} 
Tenascins comprise four members in vertebrates: tenascin- $\mathrm{C}$ (TNC), tenascin-R (TNR), tenascin-X (TNX) [referred to as tenascin-Y (TNY) in chickens], and tenascin-W (TNW) (originally named tenascin- $\mathrm{N}$ in mice) $(2,3)$. The tenascin family members have a common structure with heptad repeats, epidermal growth factor (EGF)-like repeats, fibronectin type III (FNIII)-like repeats, and a fibrinogen (FBG)-related domain. This modular structure allows tenascins to interact with multiple binding partners, including cell surface receptors, cytokines, and extracellular matrix molecules. Each of tenascins shows a unique time- and tissue specific expression pattern both during development and in adulthood (4-8). On the other hand, tenascins are also subjected to dynamic remodeling during a number of pathological conditions such as inflammation, fibrotic disorders, cardiovascular diseases, and cancer progression (9). Transcriptional control of tenascin family members for their specific expression patterns has recently been reviewed (10). Such an expression pattern of tenascins is one of the features of all matricellular proteins including tenascins $(11,12)$.

\section{TNX}

\section{Expression of TNX in Physiological and Pathological Conditions \\ Regulation of TNX Expression}

TNX expression is undetectable during early embryonic stages, but its expression increases ubiquitously in various tissues, especially in heart, skeletal muscle, and skin, during the middle embryonic stage and after birth (13-15). TNX is associated with blood vessels in most tissues and its distribution is often reciprocal to that of TNC, particularly in the skin and tissues of the digestive tract (13). Interestingly, by the analyses of TNCdeficient mice it was found that TNX does not compensate for the loss of TNC, at least in the brain (16) and during early heart development (17).

As for the regulation of TNX expression by the cellular microenvironment, brain-derived neurotrophic factor (BDNF) stimulates its mRNA expression in endothelial cells (18), whereas TNX is subjected to downregulation by glucocorticoids in fibroblasts (19). Sp1, which is a widely distributed transcription factor, is essential for expression of the mouse TNX gene (Tnxb) (20). Recently, microRNA miR-30b (21), long non-coding RNA (lncRNA) LINC01305 (22, 23), and circular RNA (circRNA) circRNA_14940 (24) have also been revealed to be key regulators of TNX expression.

\section{TNX Expression in the Nervous System}

Recently, the expression pattern and significance of TNX in the nervous system have become apparent. In the nervous system, TNX is localized in the perineurium and endoneurium of the peripheral nervous system (PNS) such as sciatic nerves $(15,25)$. Indeed, patients with TNX-deficient type EDS (classical-like EDS: clEDS) show abnormal peripheral nerves (26). TNX has been expressed in Schwann cells but not in axons (27). TNX has been mainly detected in the leptomeninges in the spinal cord and in the pia matter of the dorsal root ganglion (DRG). In the DRG, TNX is localized in satellite cells surrounding primary sensory neurons (27). In the central nervous system (CNS), TNX has been detected in the leptomeninges and choroid plexus of the adult cerebral cortex (28). Avian TNX (TNY) has been shown to inhibit neurite outgrowth and reduce the spread of growth cones (29).

\section{TNX Expression in Cancers}

Although there have been fewer reports on TNX expression in cancer compared with reports on the expression of TNC and TNW in cancer, reports on TNX expression have been increasing. TNX has been shown to be highly expressed in malignant mesothelioma $(30,31)$ and ovarian cancer (32), indicating the possibility of TNX being a novel diagnostic maker of these cancers. On the other hand, there have been several reports of TNX expression being downregulated during tumor progression in astrocytomas (33), cutaneous melanoma (34), and neurofibromatosis type 1 (35), findings that are mostly opposite to those for TNC. Intriguingly, it has also been reported that TNX has a tumor suppressor role in cervical cancer via LINC01305 expression which modulates TNX expression (22), esophageal squamous-cell carcinoma (36), and lung cancer via LINC01305 expression (23) and that TNX is downregulated in these tumors. In agreement with the tumor suppressor role of TNX in cancer progression, TNX-deficient mice with grafted melanoma cells exhibited promotion of tumor invasion and metastasis because of increased activities of matrix metalloproteinases (MMPs) $(37,38)$. Interestingly, by the analyses of TNX and TNC single and/or double deficient mice, we found out that TNX deficiency-induced tumor cell proliferation in the primary tumor site is repressed by the lack of TNC, while TNX deficiency-induced invasion to neighboring tissues is not promoted by the lack of TNC (39).

\section{Physiological Functions of TNX}

The results of a number of studies on abnormalities in mice with targeted deletion in Tnxb (40) and in clEDS patients $(26,41)$ have suggested structural roles of TNX in tissue integrity $(7,42)$. TNX possesses elastic properties in the FNIII-like domain (43) and increases the stiffness of collagen gels (44). TNX is associated with collagen fibrils within tissues and regulates collagen fibril spacing (42) via direct interaction with types I, III and V fibrillar collagens (45), types XII (46) and XIV fibril-associated collagens (45), and decorin (47). It has also been shown that TNX increases both the rate and extent of fibril formation in vivo, indicating a crucial role of TNX in collagen fibrillogenesis $(48,49)$. Taken together, the findings suggest that TNX regulates collagen deposition, collagen fiber stability and collagen mechanical properties. In addition, it has been shown that TNX binds to tropoelastin (49). Coarse and fragmented immature elastin fibers have been detected in clEDS patients, suggesting that TNX is also involved in the stability and maintenance of elastin fibers (50).

\section{Other Functions of TNX}

Fragments of TNX, especially its EGF-like repeats and FNIII-like repeats, have profound proangiogenic properties (51). Furthermore, we have shown that TNX interacts with vascular endothelial growth factor B (VEGF-B) and stimulates endothelial 
cell proliferation via simultaneous binding to VEGF receptor 1 (VEGFR-1) and VEGF-B (52). Indeed, results of in vivo studies using TNX-deficient mice have shown that TNX plays a crucial role in blood vessel formation in sciatic nerves (53) and in injuryinduced stromal angiogenesis in the cornea (54). Recently, we have reported that TNX-deficient mice display upregulation of osteoclast marker gene expression and promoted bone resorption activities due to increased multinucleated osteoclasts (55). These results provide the first evidence for the essential functions of TNX in bone metabolism such as osteoclast differentiation. These non-structural functions of TNX may be related to the structural roles of this ECM glycoprotein. The modification of the composition and organization of extracellular environment due to TNX deficiency might cause the alteration of mechanical stress to the surrounding cells, leading to the non-structural aberrations.

Alcaraz et al (56). demonstrated that the C-terminal FBGrelated domain of TNX activates the latent transforming growth factor- $\beta$ (TGF- $\beta$ ) into the active molecule and that integrin $\alpha 11 \beta 1$ is required as a cell surface receptor for TNX for this activation. They also showed that the FBG-related domain-mediated TGF- $\beta$ activation elicits the TGF- $\beta /$ Smad signaling pathway and causes epithelial-mesenchymal transition (EMT) in epithelial cells (56).

So far, a number of important phenotypes have been observed by studying TNX-deficient mice (Table 1).

\section{cIEDS Caused by TNX Deficiency}

Ehlers-Danlos syndrome (EDS) is a group of clinically and genetically heritable connective tissue disorders characterized by joint hypermobility, skin hyperextensibility, and generalized connective tissue fragility (68). So far, EDS has been classified into 14 distinct subtypes caused by defects in 20 different genes encoding fibrillar collagens and collagen-modifying proteins and ECM proteins $(69,70)$. Among the subtypes, classical-like EDS (clEDS) is caused by a complete lack of TNX due to homozygous or compound heterozygous TNX gene (TNXB) mutations with autosomal recessive inheritance, leading to nonsense-mediated decay of the mutant RNA (41). clEDS shows typical clinical hallmarks characterized by soft/velvety hyperextensible skin without atrophic scarring, generalized joint hypermobility and easy bruising as its major clinical features (41). TNX is also present in sera. The serum form of TNX (sTNX) with a molecular size of $140 \mathrm{kDa}$ is generated by cleavage of the 450 $\mathrm{kDa}$ mature form of TNX (41). The measurement of sTNX concentration is useful for the diagnosis of clEDS (71).

Mitral valve abnormality (24\%) and hypertension (24\%) have been reported as cardiovascular complications in clEDS patients (72). It has also been reported that clEDS patients exhibit rectal prolapse (18\%) and diverticulosis or diverticulitis (18\%) as gastrointestinal complications (72). Currently, these gastrointestinal complications are considered to be more common in clEDS patients $(73,74)$.

Nearly $90 \%$ of patients with EDS show chronic pain (75). clEDS patients frequently complain of chronic back pain, chronic myalgia and chronic arthralgia (72). Recent investigations of TNX-deficient mice have shown that there is a direct link between TNX deficiency and pain. For example, Aktar et al.
TABLE 1 | Tenascin-X-deficient mouse phenotypes.

\begin{tabular}{|c|c|c|}
\hline Phenotypes & & References \\
\hline \multirow[t]{7}{*}{$\begin{array}{l}\text { clEDS-related } \\
\text { phenotypes }\end{array}$} & $\begin{array}{l}\text { Hyperextensible skin, reduced tensile strength, } \\
\text { reduced collagen deposition and stability, } \\
\text { reduced fibrillar collagen, increased elastic } \\
\text { fibers }\end{array}$ & $\begin{array}{l}(40,48,49 \\
57)\end{array}$ \\
\hline & Muscle weakness, myopathic changes & $(58,59)$ \\
\hline & $\begin{array}{l}\text { Reduced diameter of myelinated fibers in } \\
\text { sciatic nerves }\end{array}$ & (59) \\
\hline & Abnormal wound healing & $(60,61)$ \\
\hline & $\begin{array}{l}\text { Gastrointestinal pain and dysfunction, } \\
\text { increased colonic afferent sensitivity and } \\
\text { increased sensory neuronal sprouting }\end{array}$ & $(62,63)$ \\
\hline & $\begin{array}{l}\text { Mechanical allodynia and hypersensitivity to } \\
\text { chemical stimuli }\end{array}$ & $(27)$ \\
\hline & $\begin{array}{l}\text { Abnormal location of vaginal plug, rectal } \\
\text { prolapse }\end{array}$ & (64) \\
\hline Behavior & $\begin{array}{l}\text { Increased anxiety, superior memory retention, } \\
\text { increased sensorimotor coordination }\end{array}$ & (65) \\
\hline $\begin{array}{l}\text { Blood vessel } \\
\text { formation and } \\
\text { neovascularization }\end{array}$ & $\begin{array}{l}\text { Abnormal blood vessel formation and less } \\
\text { neovascularization }\end{array}$ & $(53,54)$ \\
\hline $\begin{array}{l}\text { Triglyceride } \\
\text { synthesis }\end{array}$ & $\begin{array}{l}\text { Accumulation of triglycerides and altered } \\
\text { composition of triglyceride-associated fatty } \\
\text { acids }\end{array}$ & (66) \\
\hline $\begin{array}{l}\text { Bone } \\
\text { homeostasis }\end{array}$ & $\begin{array}{l}\text { Bone loss due to increased } \\
\text { osteoclastogenesis }\end{array}$ & (55) \\
\hline $\begin{array}{l}\text { Tumor } \\
\text { progression }\end{array}$ & $\begin{array}{l}\text { Promotion of invasion and metastasis of } \\
\text { melanoma cells, increased activities of MMPs }\end{array}$ & $(37,38)$ \\
\hline Liver fibrosis & $\begin{array}{l}\text { Suppression of hepatic dysfunction by } \\
\text { administration of a high-fat diet }\end{array}$ & $(67)$ \\
\hline
\end{tabular}

showed that TNX-deficient mice have hypersensitive colonic nociceptive afferents and increased sensory neuronal sprouting, leading to gastrointestinal pain and dysfunction (62). In addition, we recently reported that TNX-deficient mice exhibit mechanical allodynia and hypersensitivity to chemical stimuli and hypersensitization of myelinated $\mathrm{A} \delta$ and $\mathrm{A} \beta$ fibers (27).

\section{TNX and Fibrosis}

In a previous study, we showed that TNX contributes to liver fibrosis in TNX-deficient mice administered a high-fat and highcholesterol diet with high levels of phosphorus and calcium (HFCD) (67). Inflammation assessed by inflammatory cell infiltrates and levels of type I collagen was suppressed in TNXdeficient mice compared with that in wild-type mice. On the other hand, the TGF- $\beta$ pathway is a well-known key signaling pathway associated with hepatic stellate cell activation and fibrosis progression (76). As mentioned above, TNX affects latent TGF- $\beta$ activation and signaling (56). Thus, it is reasonable to assume that TNX, especially its FBG-related domain, contributes to liver fibrosis and inflammatory responses via the TGF- $\beta$ pathway in combination with integrin $\alpha 11 \beta 1$.

\section{Other Diseases Associated With Mutations or SNPs in TNXB}

It has been reported that another disease associated with heterozygous mutations in TNXB is primary vesicoureteral reflux (VUR) (77). There is also some evidence that single 
nucleotide polymorphisms (SNPs) in TNXB are associated with other diseases. For example, genomic studies with SNPs in genome-wide association studies revealed that two closely linked SNPs in the coding region of TNXB are associated with schizophrenia risk in a Japanese population by a case-control study (78). On the other hand, an SNP in the 5' flanking region of TNXB has been reported to be associated with systemic lupus erythematosus (SLE) (79). However, the functional implications of SNPs in TNXB relevant to these diseases remain uncertain and warrant further investigation.

\section{TNC}

\section{Context-Dependent Function of TNC}

TNC is a prototypical and most well-characterized member of the tenascin family. TNC has a variety of biological functions including regulation of cell adhesion, migration, growth and differentiation by binding through its modular structure to multiple cell surface receptors including integrins, Toll-like receptor 4 (TLR4) and syndecan-4 $(80,81)$. TNC also binds to cytokines such as fibroblast growth factors (FGFs), plateletderived growth factors (PDGFs) and TGF- $\beta$ family members among others, thus regulating the cellular behavior and organization of the extracellular matrix.

The expression of TNC is regulated during embryonic development with a specific time and spatial pattern, and its expression is greatly diminished in adult tissue. Although the specific expression pattern of TNC was suggestive of its role in embryogenesis, mice with genetic deletion of TNC were born and grew without any gross abnormality and were fertile (16). Later, it was demonstrated that TNC-deficient mice exhibit abnormalities in their behavior and in the cytoarchitecture of the brain (82). Considering the extensive expression of TNC during embryogenesis, TNC may have more roles in fine tuning animal development that are yet to be clarified.

TNC is transiently and specifically re-expressed upon acute inflammation and is persistently expressed upon chronic inflammation (83-85). Growing evidence has suggested that TNC is a proinflammatory factor and plays a deleterious role in fibrotic diseases (86-88). Interestingly, several lines of evidence have suggested that TNC also acts as an anti-inflammatory factor. For example, it was shown that the first two alternative spliced FNIII-like repeats suppress in vitro $\mathrm{T}$ cell activation (89). The results of in vivo studies showed that chemically induced inflammatory dermatitis (90) and Habu-snake venom-induced glomerulonephritis (91) develop more severely in TNC-deficient mice than in wild-type mice. Such bimodal activities, namely proinflammatory or antiinflammatory activities, of TNC can have paradoxical effects and may influence many aspects of the immune response in a contextdependent manner.

The context-dependent function of TNC seems to be derived from its multidomain structure, which allows TNC to interact with multiple extracellular matrix and cytokines (81). In addition, TNC gene can generate multiple variants of TNC protein by alternative splicing of mRNA in tissue- and disease-specific manners (92), and proteolytic processing by various proteases, of which significance has been demonstrated by experiments with domain-specific antibodies and recombinant proteins.

\section{Pathophysiological Role of TNC in Cardiac Diseases}

TNC is reported to be involved in a variety of cardiovascular diseases $(83,93,94)$. In the pathogenesis of myocardial damage and cardiac dysfunction, animal experiments have demonstrated that TNC is involved in adverse remodeling of myocardium due to myocardial infarction $(95,96)$ and myocarditis $(97)$. TNC has been reported to promote myocardial hypertrophy, fibrosis (98, 99) and cardiac dysfunction (100) in animal models of cardiac hypertrophy and myocardial infarction. Being consistent with those findings, TNC has been shown to promote cardiac fibrosis in an angiotensin II-induced hypertrophy model (101). However, another study showed that TNC attenuated cardiac fibrosis due to pressure overload or angiotensin II infusion (102). These contradictory findings may be due to the fact that the adverse effect of TNC was demonstrated in a BALB/c background of the mouse strain, while its beneficial effect was shown in the background of $\mathrm{C} 57 \mathrm{BL} / 6$. It was further speculated that the difference may reflect the predominant immune responses of Th2 in BALB/c and Th1 in C57BL/6, although this hypothesis awaits formal proof (103).

\section{Pathophysiological Role of TNC in Vascular Diseases}

With regard to vascular diseases, TNC has been reported to be atherogenic by stimulating TLR4-dependent foam cell formation (104). However, TNC has also been reported to be anti-atherogenic since TNC-deficient mice showed mast cell accumulation and intraplaque hemorrhage $(105,106)$. Similarly, expression of TNC may prevent the rupture of cerebral aneurysm by promoting fibrosis of the aneurysmal wall $(107,108)$, while it may be deleterious by exacerbating acute vasospastic response and exacerbate cerebral injury after subarachnoidal hemorrhage $(109,110)$. Expression of TNC by neurohumoral stress protects the aorta from acute aortic dissection (111) (Figure 1), while it seems to have no impact on the development of abdominal aortic aneurysm, although it was highly expressed in the aneurysmal tissue (112). Therefore, TNC can be either disease-promotive, disease-preventive or neutral in cardiovascular diseases (94), underscoring the context-dependent function of TNC, as demonstrated also in various animal models of non-cardiovascular diseases.

\section{TNC as a Biomarker of Tissue Damage}

While the role of TNC is context-dependent and can be detrimental or beneficial, it has been established that TNC is expressed in various cardiovascular diseases in clinical settings (93). TNC is elevated after myocardial injury due to myocardial infarction (113) or due to acute (114) or chronic myocarditis (115). TNC is also elevated in hypertrophic (116) and dilated cardiomyopathies (117). In addition, TNC is elevated in heart failure with preserved ejection fraction (HFpEF) (118) and in right ventricular failure (119). TNC is not only deposited in the 


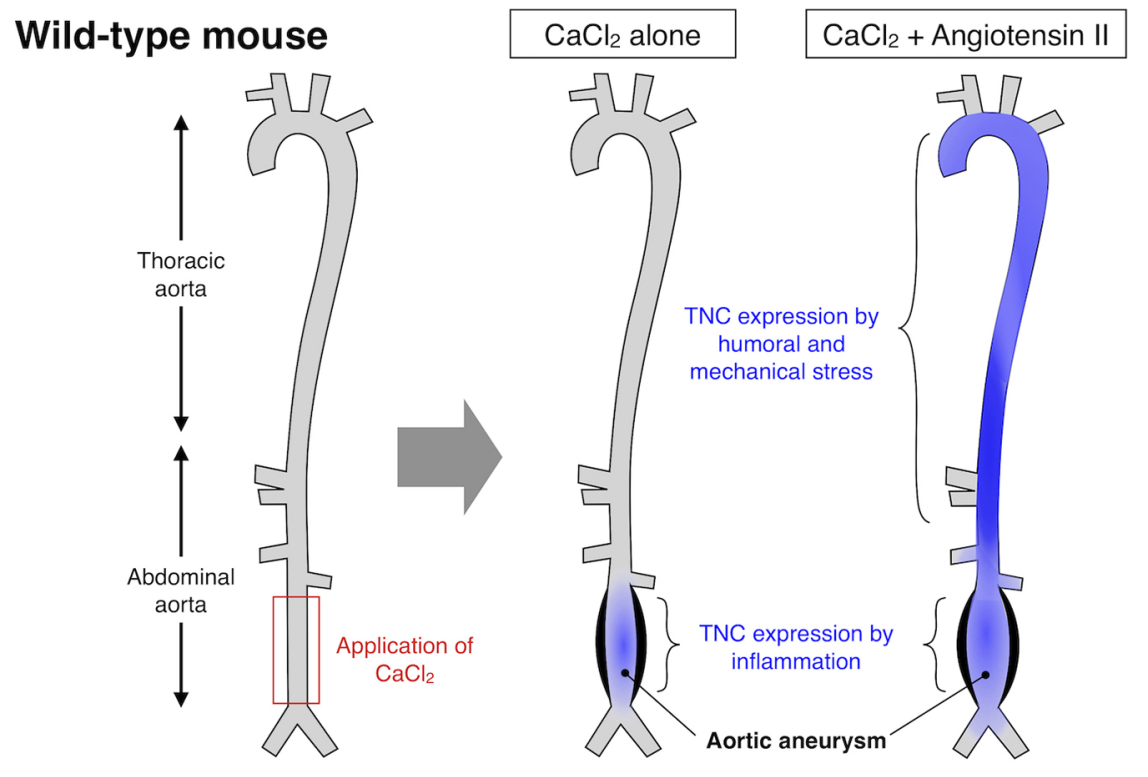

TNC-deficient mouse

$\mathrm{CaCl}_{2}+$ Angiotensin II

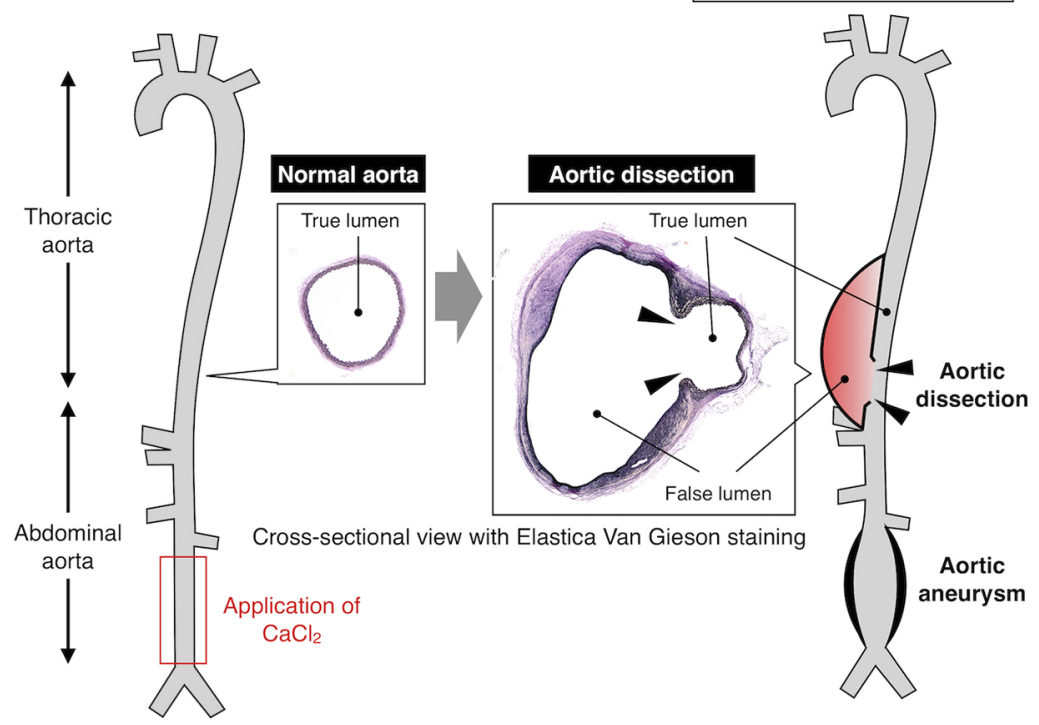

FIGURE 1 | Expression and function of TNC in mouse model of aortic diseases. Upper panel: Application of $\mathrm{CaCl}_{2}$ solution to the lower abdominal aorta caused local inflammation and formation of aortic aneurysm. Continuous infusion of angiotensin II after the $\mathrm{CaCl}_{2}$ application resulted in higher wall stress and formation of larger aortic aneurysm. TNC was induced in the lower abdominal aorta by $\mathrm{CaCl}_{2}$-induced local inflammation, and in the thoracic and upper abdominal aorta due to the angiotensin II-induced higher wall stress, as illustrated by the blue color. Lower panel: TNC-deficient mice developed aortic aneurysm comparable to wild-type mice by $\mathrm{CaCl}_{2}$ application in the presence or absence of angiotensin II. On the other hand, TNC-deficient mice developed aortic dissection in the thoracic and upper abdominal aorta that was characterized by the disruption of the aortic wall (arrowheads) and the formation of false lumen (red color). These findings indicate that TNC does not play a major role in the destructive inflammation in the aortic aneurysm, while it is critical for protecting the aortic wall from dissection, exemplifying the context-dependent function of TNC (111).

damaged tissue but also liberated in circulating blood flow. It has been proposed that TNC can serve as a prognostic marker for heart failure due to these diseases. While B-type natriuretic peptide (BNP) is an established prognostic marker for heart failure, the combination of BNP and TNC may be more precise than BNP or
TNC alone for patients with dilated cardiomyopathy (120). Furthermore, reverse remodeling of the ventricle in heart failure patients due to cardiac resynchronization therapy was shown to be associated with reduction in serum TNC level, suggesting that TNC may reflect ongoing myocardial damage (121). 
Since TNC is induced by various inflammatory mediators, it may also reflect the disease activities of inflammatory cardiovascular diseases including Kawasaki disease $(122,123)$ and cardiac sarcoidosis (124). TNC is expressed locally in the tissue of coronary atherosclerosis (125) and abdominal aortic aneurysm $(112,126)$, and its expression is elevated in serum of patients with these diseases (127). The serum level of TNC is elevated in patients with acute aortic dissection and its elevated level is associated with acute mortality (128), as well as chronic prognosis $(129,130)$. TNC is also elevated in cerebrospinal fluid after subarachnoidal hemorrhage and may predict the development of cerebral vasospasm (131). Elevated serum TNC is not only associated with specific diseases but also with the mortality and the development of cardiovascular diseases in patients with chronic kidney disease (132) and it is also associated with major adverse cardiovascular events and death in individuals with type 2 diabetes mellitus (133). In addition to the serum level, local deposition of TNC may serve as a marker of tissue damage, as demonstrated in animal models of myocarditis (134) and myocardial infarction (135). Therefore, quantitative detection of systemic and local levels of TNC may have a clinical value for monitoring inflammation and tissue damage both in acute and chronic diseases in order to realize precision medicine for better outcomes by optimizing the clinical practice for individual requirement.

Considering the fact that the structure of TNC can be altered in a disease-specific manner, domain-specific detection of TNC may also have a clinical value (92). For example, isoform-specific expression of TNC was demonstrated in the lung tissue of experimental pulmonary hypertension (136) and in the serum of the patients (137). This means that care should be taken which isoform of TNC is being measured to evaluate its significance as a biomarker in a particular clinical setting, as well as the normal range of TNC concentration. Because of the significance of the different TNC isoforms, domain-specific monoclonal antibodies for TNC would have potential clinical values both as diagnostic tools to evaluate the disease conditions, and as therapeutic tools to target a particular function of TNC or a particular tissue that expresses the corresponding TNC isoform (92).

\section{CONCLUSIONS}

TNX and TNC have distinct roles in physiological and pathological conditions. In a physiological condition, TNX is

\section{REFERENCES}

1. Adams JC, Watt FM. Regulation of development and differentiation by the extracellular matrix. Development (1993) 117:1183-98.

2. Chiquet-Ehrismann R, Tucker RP. Tenascins and the importance of adhesion modulation. Cold Spring Harb Perspect Biol (2011) 3:a004960. doi: 10.1101/cshperspect.a004960

3. Adams JC, Chiquet-Ehrismann R, Tucker RP. The evolution of tenascins and fibronectin. Cell Adh Migr (2015) 9:22-33. doi: 10.4161/19336918.2014.970030

4. Tucker RP, Chiquet-Ehrismann R. The regulation of tenascin expression by tissue microenvironments. Biochim Biophys Acta (2009) 1793:888-92. doi: 10.1016/j.bbamcr.2008.12.012 involved in the structural integrity of collagen fibrils. TNX also has a tumor suppressor role, a proangiogenic property, a role in osteoclast differentiation, and a role in TGF- $\beta$ activation. On the other hand, in a pathological condition such as TNX deficiency, its absence causes clEDS with major clinical features such as hyperextensible skin without atrophic scarring, generalized joint hypermobility and easy bruising. Interestingly, TNX deficiency is involved in pain and fibrosis. The underlying molecular mechanisms for pain and suppression of fibrosis caused by TNX deficiency need to be elucidated in more detail.

The physiological role of TNC is yet to be clarified. Although genetic deletion of TNC in mice resulted in no gross abnormality of the animals, the possibility remains that TNC plays a role in cell differentiation and tissue organization during embryogenesis. On the other hand, accumulating evidence indicates that TNC is reexpressed and actively participates in the pathogenesis of various diseases with tissue damage. The context-dependent function of TNC, possibly due to its modular structure and multiple binding partners, makes it difficult to interpret the experimental results as to whether expression of TNC is detrimental or beneficial. Nonetheless, expression of TNC seems to be a sensitive marker for tissue damage both in cardiovascular and non-cardiovascular diseases including cancer. Considering the wide range of physiological and pathophysiological functions of tenascins and their specific expression patterns, basic and clinical studies of tenascin family would be fruitful for delineating their precise roles and their clinical implications both in normal and abnormal conditions.

\section{AUTHOR CONTRIBUTIONS}

KM and HA designed and wrote this manuscript. All authors contributed to the article and approved the submitted version.

\section{FUNDING}

This work was supported by the Japan Society for the Promotion of Science KAKENHI grant number 19K08470 to KM and 19H03743 to HA from the Ministry of Education, Culture, Sports, Science and Technology of Japan.

5. Chiquet-Ehrismann R, Orend G, Chiquet M, Tucker RP, Midwood KS. Tenascins in stem cell niches. Matrix Biol (2014) 37:112-23. doi: 10.1016/ j.matbio.2014.01.007

6. Jakovcevski I, Miljkovic D, Schachner M, Andjus PR. Tenascins and inflammation in disorders of the nervous system. Amino Acids (2013) 44:1115-27. doi: 10.1007/s00726-012-1446-0

7. Valcourt U, Alcaraz LB, Exposito JY, Lethias C, Bartholin L. Tenascin-X: beyond the architectural function. Cell Adh Migr (2015) 9:154-65. doi: $10.4161 / 19336918.2014 .994893$

8. Tucker RP, Degen M. The expression and possible functions of tenascin-W during development and disease. Front Cell Dev Biol (2019) 7:53 doi: $10.3389 /$ fcell.2019.00053 
9. Chiquet-Ehrismann R, Chiquet M. Tenascins: regulation and putative functions during pathological stress. J Pathol (2003) 200:488-99. doi: $10.1002 /$ path. 1415

10. Chiovaro F, Chiquet-Ehrismann R, Chiquet M. Transcriptional regulation of tenascin genes. Cell Adh Migr (2015) 9:34-47. doi: 10.1080/ 19336918.2015.1008333

11. Bornstein P. Diversity of function is inherent in matricellular proteins: an appraisal of thrombospondin 1. J Cell Biol (1995) 130:503-6. doi: 10.1083/ jcb.130.3.503

12. Bornstein P, Sage EH. Matricellular proteins: extracellular modulators of cell function. Curr Opin Cell Biol (2002) 14:608-16. doi: 10.1016/s0955-0674(02) 00361-7

13. Matsumoto K, Saga Y, Ikemura T, Sakakura T, Chiquet-Ehrismann R. The distribution of tenascin-X is distinct and often reciprocal to that of tenascinC. J Cell Biol (1994) 125:483-93. doi: 10.1083/jcb.125.2.483

14. Burch GH, Bedolli MA, McDonough S, Rosenthal SM, Bristow J. Embryonic expression of tenascin- $\mathrm{X}$ suggests a role in limb, muscle, and heart development. Dev Dyn (1995) 203:491-504. doi: 10.1002/aja.1002030411

15. Geffrotin C, Garrido JJ, Tremet L, Vaiman M. Distinct tissue distribution in pigs of tenascin-X and tenascin-C transcripts. Eur J Biochem (1995) 231:8392. doi: 10.1111/j.1432-1033.1995.tb20673.x

16. Saga Y, Yagi T, Ikawa Y, Sakakura T, Aizawa S. Mice develop normally without tenascin. Genes Dev (1992) 6:1821-31. doi: 10.1101/gad.6.10. 1821

17. Imanaka-Yoshida K, Matsumoto K, Hara M, Sakakura T, Yoshida T. The dynamic expression of tenascin- $\mathrm{C}$ and tenascin- $\mathrm{X}$ during early heart development in the mouse. Differentiation (2003) 71:291-8. doi: 10.1046/ j.1432-0436.2003.7104506.x

18. Takeda K, Shiba H, Mizuno N, Hasegawa N, Mouri Y, Hirachi A, et al. Brain-derived neurotrophic factor enhances periodontal tissue regeneration. Tissue Eng (2005) 11:1618-29. doi: 10.1089/ten.2005.11.1618

19. Sakai T, Furukawa Y, Chiquet-Ehrismann R, Nakamura M, Kitagawa S, Ikemura $\mathrm{T}$, et al. Tenascin-X expression in tumor cells and fibroblasts: glucocorticoids as negative regulators in fibroblasts. J Cell Sci (1996) 109( Pt 8):2069-77

20. Minamitani T, Ariga H, Matsumoto K. Transcription factor Sp1 activates the expression of the mouse tenascin-X gene. Biochem Biophys Res Commun (2000) 267:626-31. doi: 10.1006/bbrc.1999.2006

21. Tafazzoli A, Forstner AJ, Broadley D, Hofmann A, Redler S, Petukhova L, et al. Genome-wide microRNA analysis implicates $\mathrm{miR}-30 \mathrm{~b} / \mathrm{d}$ in the etiology of alopecia areata. J Invest Dermatol (2018) 138:549-56. doi: 10.1016/ j.jid.2017.09.046

22. Yan SP, Chu DX, Qiu HF, Xie Y, Wang CF, Zhang JY, et al. LncRNA LINC01305 silencing inhibits cell epithelial-mesenchymal transition in cervical cancer by inhibiting TNXB-mediated PI3K/Akt signalling pathway. J Cell Mol Med (2019) 23:2656-66. doi: 10.1111/jcmm.14161

23. Yan F, Liu SW, Li XY, Li CC, Wu Y. Silencing LncRNA LINC01305 inhibits epithelial mesenchymal transition in lung cancer cells by regulating TNXBmediated PI3K/Akt signaling pathway. J Biol Regul Homeost Agents (2020) 34:499-508. doi: 10.23812/20-73-a-33

24. Wu L, Zhou R, Diao J, Chen X, Huang J, Xu K, et al. Differentially expressed circular RNAs in orbital adipose/connective tissue from patients with thyroid-associated ophthalmopathy. Exp Eye Res (2020) 196:108036. doi: 10.1016/j.exer.2020.108036

25. Matsumoto K, Sawa H, Sato M, Orba Y, Nagashima K, Ariga H. Distribution of extracellular matrix tenascin-X in sciatic nerves. Acta Neuropathol (2002) 104:448-54. doi: 10.1007/s00401-002-0577-x

26. Burch GH, Gong Y, Liu W, Dettman RW, Curry CJ, Smith L, et al. Tenascin$\mathrm{X}$ deficiency is associated with Ehlers-Danlos syndrome. Nat Genet (1997) 17:104-8. doi: 10.1038/ng0997-104

27. Okuda-Ashitaka E, Kakuchi Y, Kakumoto H, Yamanishi S, Kamada H, Yoshidu T, et al. Mechanical allodynia in mice with tenascin-X deficiency associated with Ehlers-Danlos syndrome. Sci Rep (2020) 10:6569. doi: 10.1038/s41598-020-63499-2

28. Imura K, Sato I. Novel localization of tenascin-X in adult mouse leptomeninges and choroid plexus. Ann Anat (2008) 190:324-8. doi: 10.1016/j.aanat.2008.04.003
29. Tucker RP, Hagios C, Santiago A, Chiquet-Ehrismann R. Tenascin-Y is concentrated in adult nerve roots and has barrier properties in vitro. J Neurosci Res (2001) 66:439-47. doi: 10.1002/jnr.1236

30. Yuan Y, Nymoen DA, Stavnes HT, Rosnes AK, Bjørang O, Wu C, et al. Tenascin-X is a novel diagnostic marker of malignant mesothelioma. Am J Surg Pathol (2009) 33:1673-82. doi: 10.1097/PAS.0b013e3181b6bde3

31. Nakayama K, Seike M, Noro R, Takeuchi S, Matsuda K, Kunugi S, et al. Tenascin XB is a novel diagnostic marker for malignant mesothelioma. Anticancer Res (2019) 39:627-33. doi: 10.21873/anticanres.13156

32. Kramer M, Pierredon S, Ribaux P, Tille JC, Petignat P, Cohen M. Secretome identifies tenascin- $\mathrm{X}$ as a potent marker of ovarian cancer. BioMed Res Int (2015) 2015:208017. doi: 10.1155/2015/208017

33. Hasegawa K, Yoshida T, Matsumoto K, Katsuta K, Waga S, Sakakura T. Differential expression of tenascin-C and tenascin-X in human astrocytomas. Acta Neuropathol (1997) 93:431-7. doi: 10.1007/s00401 0050636

34. Geffrotin C, Horak V, Créchet F, Tricaud Y, Lethias C, Vincent-Naulleau S, et al. Opposite regulation of tenascin-C and tenascin-X in MeLiM swine heritable cutaneous malignant melanoma. Biochim Biophys Acta (2000) 1524:196-202. doi: 10.1016/s0304-4165(00)00158-6

35. Lévy P, Ripoche H, Laurendeau I, Lazar V, Ortonne N, Parfait B, et al. Microarray-based identification of tenascin $\mathrm{C}$ and tenascin $\mathrm{XB}$, genes possibly involved in tumorigenesis associated with neurofibromatosis type 1. Clin Cancer Res (2007) 13:398-407. doi: 10.1158/1078-0432.Ccr-06-0182

36. Yang N, Tian J, Wang X, Mei S, Zou D, Peng X, et al. A functional variant in TNXB promoter associates with the risk of esophageal squamous-cell carcinoma. Mol Carcinog (2020) 59:439-46. doi: 10.1002/mc.23166

37. Matsumoto K, Takayama N, Ohnishi J, Ohnishi E, Shirayoshi Y, Nakatsuji $\mathrm{N}$, et al. Tumour invasion and metastasis are promoted in mice deficient in tenascin-X. Genes Cells (2001) 6:1101-11. doi: 10.1046/j.13652443.2001.00482.x

38. Matsumoto K, Minamitani T, Orba $\mathrm{Y}$, Sato M, Sawa H, Ariga H. Induction of matrix metalloproteinase- 2 by tenascin-X deficiency is mediated through the c-Jun N-terminal kinase and protein tyrosine kinase phosphorylation pathway. Exp Cell Res (2004) 297:404-14. doi: 10.1016/j.yexcr.2004.03.041

39. Matsumoto K, Takahashi K, Yoshiki A, Kusakabe M, Ariga H. Invasion of melanoma in double knockout mice lacking tenascin-X and tenascin-C. Jpn J Cancer Res (2002) 93:968-75. doi: 10.1111/j.1349-7006.2002.tb02472.x

40. Mao JR, Taylor G, Dean WB, Wagner DR, Afzal V, Lotz JC, et al. Tenascin-X deficiency mimics Ehlers-Danlos syndrome in mice through alteration of collagen deposition. Nat Genet (2002) 30:421-5. doi: 10.1038/ng850

41. Schalkwijk J, Zweers MC, Steijlen PM, Dean WB, Taylor G, van Vlijmen IM, et al. A recessive form of the Ehlers-Danlos syndrome caused by tenascin-X deficiency. N Engl J Med (2001) 345:1167-75. doi: 10.1056/NEJMoa002939

42. Bristow J, Carey W, Egging D, Schalkwijk J. Tenascin-X, collagen, elastin, and the Ehlers-Danlos syndrome. Am J Med Genet C Semin Med Genet (2005) 139c:24-30. doi: 10.1002/ajmg.c.30071

43. Jollymore A, Lethias C, Peng Q, Cao Y, Li H. Nanomechanical properties of tenascin-X revealed by single-molecule force spectroscopy. J Mol Biol (2009) 385:1277-86. doi: 10.1016/j.jmb.2008.11.038

44. Margaron Y, Bostan L, Exposito JY, Malbouyres M, Trunfio-Sfarghiu AM, Berthier Y, et al. Tenascin-X increases the stiffness of collagen gels without affecting fibrillogenesis. Biophys Chem (2010) 147:87-91. doi: 10.1016/ j.bpc.2009.12.011

45. Lethias C, Carisey A, Comte J, Cluzel C, Exposito JY. A model of tenascin-X integration within the collagenous network. FEBS Lett (2006) 580:6281-5. doi: 10.1016/j.febslet.2006.10.037

46. Veit G, Hansen U, Keene DR, Bruckner P, Chiquet-Ehrismann R, Chiquet $\mathrm{M}$, et al. Collagen XII interacts with avian tenascin-X through its NC3 domain. J Biol Chem (2006) 281:27461-70. doi: 10.1074/jbc.M603147200

47. Elefteriou F, Exposito JY, Garrone R, Lethias C. Binding of tenascin-X to decorin. FEBS Lett (2001) 495:44-7. doi: 10.1016/s0014-5793(01)02361-4

48. Minamitani T, Ikuta T, Saito Y, Takebe G, Sato M, Sawa H, et al. Modulation of collagen fibrillogenesis by tenascin-X and type VI collagen. Exp Cell Res (2004) 298:305-15. doi: 10.1016/j.yexcr.2004.04.030

49. Egging D, van den Berkmortel F, Taylor G, Bristow J, Schalkwijk J. Interactions of human tenascin-X domains with dermal extracellular 
matrix molecules. Arch Dermatol Res (2007) 298:389-96. doi: 10.1007/ s00403-006-0706-9

50. Zweers MC, van Vlijmen-Willems IM, van Kuppevelt TH, Mecham RP, Steijlen PM, Bristow J, et al. Deficiency of tenascin-X causes abnormalities in dermal elastic fiber morphology. J Invest Dermatol (2004) 122:885-91. doi: $10.1111 / \mathrm{j} .0022-202 X .2004 .22401 . \mathrm{x}$

51. Demidova-Rice TN, Geevarghese A, Herman IM. Bioactive peptides derived from vascular endothelial cell extracellular matrices promote microvascular morphogenesis and wound healing in vitro. Wound Repair Regen (2011) 19:59-70. doi: 10.1111/j.1524-475X.2010.00642.x

52. Ikuta $\mathrm{T}$, Ariga $\mathrm{H}$, Matsumoto $\mathrm{K}$. Extracellular matrix tenascin- $\mathrm{X}$ in combination with vascular endothelial growth factor B enhances endothelial cell proliferation. Genes Cells (2000) 5:913-27. doi: 10.1046/ j.1365-2443.2000.00376.x

53. Sakai H, Yokota S, Kajitani N, Yoneyama T, Kawakami K, Yasui Y, et al. A potential contribution of tenascin-X to blood vessel formation in peripheral nerves. Neurosci Res (2017) 124:1-7. doi: 10.1016/j.neures.2017.06.003

54. Sumioka T, Iwanishi H, Okada Y, Nidegawa Y, Miyajima M, Matsumoto KI, et al. Loss of tenascin $\mathrm{X}$ gene function impairs injury-induced stromal angiogenesis in mouse corneas. J Cell Mol Med (2018) 22:948-56. doi: $10.1111 / \mathrm{jcmm} .13397$

55. Kajitani N, Yamada T, Kawakami K, Matsumoto KI. TNX deficiency results in bone loss due to an increase in multinucleated osteoclasts. Biochem Biophys Res Commun (2019) 512:659-64. doi: 10.1016/j.bbrc.2019.03.134

56. Alcaraz LB, Exposito JY, Chuvin N, Pommier RM, Cluzel C, Martel S, et al. Tenascin-X promotes epithelial-to-mesenchymal transition by activating latent TGF- $\beta$. J Cell Biol (2014) 205:409-28. doi: 10.1083/jcb.201308031

57. Minamitani T, Ariga H, Matsumoto K. Deficiency of tenascin-X causes a decrease in the level of expression of type VI collagen. Exp Cell Res (2004) 297:49-60. doi: 10.1016/j.yexcr.2004.03.002

58. Huijing PA, Voermans NC, Baan GC, Buse TE, van Engelen BG, de Haan A. Muscle characteristics and altered myofascial force transmission in tenascin$\mathrm{X}$-deficient mice, a mouse model of Ehlers-Danlos syndrome. J Appl Physiol (1985) (2010) 109:986-95. doi: 10.1152/japplphysiol.00723.2009

59. Voermans NC, Verrijp K, Eshuis L, Balemans MC, Egging D, Sterrenburg E, et al. Mild muscular features in tenascin-X knockout mice, a model of Ehlers-Danlos syndrome. Connect Tissue Res (2011) 52:422-32. doi: 10.3109/03008207.2010.551616

60. Egging D, van Vlijmen-Willems I, van Tongeren T, Schalkwijk J, Peeters A. Wound healing in tenascin-X deficient mice suggests that tenascin- $X$ is involved in matrix maturation rather than matrix deposition. Connect Tissue Res (2007) 48:93-8. doi: 10.1080/03008200601166160

61. Hashimoto K, Kajitani N, Miyamoto Y, Matsumoto KI. Wound healingrelated properties detected in an experimental model with a collagen gel contraction assay are affected in the absence of tenascin-X. Exp Cell Res (2018) 363:102-13. doi: 10.1016/j.yexcr.2017.12.025

62. Aktar R, Peiris M, Fikree A, Cibert-Goton V, Walmsley M, Tough IR, et al. The extracellular matrix glycoprotein tenascin-X regulates peripheral sensory and motor neurones. J Physiol (2018) 596:4237-51. doi: 10.1113/ jp276300

63. Aktar R, Peiris M, Fikree A, Eaton S, Kritas S, Kentish SJ, et al. A novel role for the extracellular matrix glycoprotein-Tenascin-X in gastric function. J Physiol (2019) 597:1503-15. doi: 10.1113/jp277195

64. Egging DF, van Vlijmen-Willems I, Choi J, Peeters AC, van Rens D, Veit G, et al. Analysis of obstetric complications and uterine connective tissue in tenascin-X-deficient humans and mice. Cell Tissue Res (2008) 332:523-32. doi: 10.1007/s00441-008-0591-y

65. Kawakami K, Matsumoto K. Behavioral alterations in mice lacking the gene for tenascin-X. Biol Pharm Bull (2011) 34:590-3. doi: 10.1248/bpb.34.590

66. Matsumoto K, Sato T, Oka S, Orba Y, Sawa H, Kabayama K, et al. Triglyceride accumulation and altered composition of triglycerideassociated fatty acids in the skin of tenascin-X-deficient mice. Genes Cells (2004) 9:737-48. doi: 10.1111/j.1356-9597.2004.00755.x

67. Yamaguchi S, Kawakami K, Satoh K, Fukunaga N, Akama K, Matsumoto KI. Suppression of hepatic dysfunction in tenascin-X-deficient mice fed a high -fat diet. Mol Med Rep (2017) 16:4061-7. doi: 10.3892/mmr.2017.7052

68. De Paepe A, Malfait F. The Ehlers-Danlos syndrome, a disorder with many faces. Clin Genet (2012) 82:1-11. doi: 10.1111/j.1399-0004.2012.01858.x
69. Malfait F, Francomano C, Byers P, Belmont J, Berglund B, Black J, et al. The 2017 international classification of the Ehlers-Danlos syndromes. Am J Med Genet C Semin Med Genet (2017) 175:8-26. doi: 10.1002/ajmg.c.31552

70. Malfait F, Castori M, Francomano CA, Giunta C, Kosho T, Byers PH. The Ehlers-Danlos syndromes. Nat Rev Dis Primers (2020) 6:64. doi: 10.1038/ s41572-020-0194-9

71. Yamada K, Watanabe A, Takeshita H, Matsumoto KI. A method for quantification of serum tenascin-X by nano-LC/MS/MS. Clin Chim Acta (2016) 459:94-100. doi: 10.1016/j.cca.2016.05.022

72. Demirdas S, Dulfer E, Robert L, Kempers M, van Beek D, Micha D, et al. Recognizing the tenascin-X deficient type of Ehlers-Danlos syndrome: a cross-sectional study in 17 patients. Clin Genet (2017) 91:411-25. doi: $10.1111 /$ cge. 12853

73. Sakiyama T, Kubo A, Sasaki T, Yamada T, Yabe N, Matsumoto K, et al. Recurrent gastrointestinal perforation in a patient with Ehlers-Danlos syndrome due to tenascin-X deficiency. J Dermatol (2015) 42:511-4. doi: $10.1111 / 1346-8138.12829$

74. Green C, Ghali N, Akilapa R, Angwin C, Baker D, Bartlett M, et al. Classicallike Ehlers-Danlos syndrome: a clinical description of 20 newly identified individuals with evidence of tissue fragility. Genet Med (2020) 22:1576-82. doi: 10.1038/s41436-020-0850-1

75. Voermans NC, Knoop H, Bleijenberg G, van Engelen BG. Pain in EhlersDanlos syndrome is common, severe, and associated with functional impairment. J Pain Symptom Manage (2010) 40:370-8. doi: 10.1016/ j.jpainsymman.2009.12.026

76. Xu F, Liu C, Zhou D, Zhang L. TGF- $\beta$ /SMAD pathway and its regulation in hepatic fibrosis. J Histochem Cytochem (2016) 64:157-67. doi: 10.1369/ 0022155415627681

77. Gbadegesin RA, Brophy PD, Adeyemo A, Hall G, Gupta IR, Hains D, et al. TNXB mutations can cause vesicoureteral reflux. J Am Soc Nephrol (2013) 24:1313-22. doi: 10.1681/asn.2012121148

78. Tochigi $\mathrm{M}$, Zhang $\mathrm{X}$, Ohashi J, Hibino H, Otowa T, Rogers $\mathrm{M}$, et al. Association study between the TNXB locus and schizophrenia in a Japanese population. Am J Med Genet B Neuropsychiatr Genet (2007) 144b:305-9. doi: 10.1002/ajmg.b.30441

79. Kamatani Y, Matsuda K, Ohishi T, Ohtsubo S, Yamazaki K, Iida A, et al. Identification of a significant association of a single nucleotide polymorphism in TNXB with systemic lupus erythematosus in a Japanese population. J Hum Genet (2008) 53:64-73. doi: 10.1007/ s10038-007-0219-1

80. Imanaka-Yoshida $\mathrm{K}$, Aoki $\mathrm{H}$. Tenascin-C and mechanotransduction in the development and diseases of cardiovascular system. Front Physiol (2014) 5:283:283. doi: 10.3389/fphys.2014.00283

81. Midwood KS, Chiquet M, Tucker RP, Orend G. Tenascin-C at a glance. J Cell Sci (2016) 129:4321-7. doi: 10.1242/jcs.190546

82. Mackie EJ, Tucker RP. The tenascin-C knockout revisited. J Cell Sci (1999) 112( Pt 22):3847-53.

83. Midwood KS, Hussenet T, Langlois B, Orend G. Advances in tenascin-C biology. Cell Mol Life Sci (2011) 68:3175-99. doi: 10.1007/s00018-011-07836

84. Midwood KS, Orend G. The role of tenascin-C in tissue injury and tumorigenesis. J Cell Commun Signal (2009) 3:287-310. doi: 10.1007/ s12079-009-0075-1

85. Marzeda AM, Midwood KS. Internal affairs: tenascin-C as a clinically relevant, endogenous driver of innate immunity. J Histochem Cytochem (2018) 66:289-304. doi: 10.1369/0022155418757443

86. Kasprzycka M, Hammarström C, Haraldsen G. Tenascins in fibrotic disorders-from bench to bedside. Cell Adh Migr (2015) 9:83-9. doi: 10.4161/19336918.2014.994901

87. El-Karef A, Yoshida T, Gabazza EC, Nishioka T, Inada H, Sakakura T, et al. Deficiency of tenascin-C attenuates liver fibrosis in immune-mediated chronic hepatitis in mice. J Pathol (2007) 211:86-94. doi: 10.1002/path.2099

88. Carey WA, Taylor GD, Dean WB, Bristow JD. Tenascin-C deficiency attenuates TGF-B-mediated fibrosis following murine lung injury. Am J Physiol Lung Cell Mol Physiol (2010) 299:L785-93. doi: 10.1152/ ajplung.00385.2009

89. Puente Navazo MD, Valmori D, Rüegg C. The alternatively spliced domain $\mathrm{TnFnIII} \mathrm{A1A2}$ of the extracellular matrix protein tenascin-C suppresses 
activation-induced T lymphocyte proliferation and cytokine production. J Immunol (2001) 167:6431-40. doi: 10.4049/jimmunol.167.11.6431

90. Koyama Y, Kusubata M, Yoshiki A, Hiraiwa N, Ohashi T, Irie S, et al. Effect of tenascin-C deficiency on chemically induced dermatitis in the mouse. J Invest Dermatol (1998) 111:930-5. doi: 10.1046/j.15231747.1998.00401.x

91. Nakao N, Hiraiwa N, Yoshiki A, Ike F, Kusakabe M. Tenascin-C promotes healing of Habu-snake venom-induced glomerulonephritis: studies in knockout congenic mice and in culture. Am J Pathol (1998) 152:1237-45.

92. Giblin SP, Midwood KS. Tenascin-C: Form versus function. Cell Adh Migr (2015) 9:48-82. doi: 10.4161/19336918.2014.987587

93. Golledge J, Clancy P, Maguire J, Lincz L, Koblar S. The role of tenascin C in cardiovascular disease. Cardiovasc Res (2011) 92:19-28. doi: 10.1093/cvr/ cvr183

94. Imanaka-Yoshida K. Tenascin-C in cardiovascular tissue remodeling: from development to inflammation and repair. Circ J (2012) 76:2513-20. doi: 10.1253 /circj.cj-12-1033

95. Nishioka T, Onishi K, Shimojo N, Nagano Y, Matsusaka H, Ikeuchi M, et al. Tenascin-C may aggravate left ventricular remodeling and function after myocardial infarction in mice. Am J Physiol Heart Circ Physiol (2010) 298: H1072-8. doi: 10.1152/ajpheart.00255.2009

96. Santer D, Nagel F, Goncalves IF, Kaun C, Wojta J, Fagyas M, et al. Tenascin$\mathrm{C}$ aggravates ventricular dilatation and angiotensin-converting enzyme activity after myocardial infarction in mice. ESC Heart Fail (2020) 7:211322. doi: $10.1002 /$ ehf2.12794

97. Machino-Ohtsuka T, Tajiri K, Kimura T, Sakai S, Sato A, Yoshida T, et al. Tenascin-C aggravates autoimmune myocarditis via dendritic cell activation and Th17 cell differentiation. J Am Heart Assoc (2014) 3:e001052. doi: 10.1161/jaha.114.001052

98. Podesser BK, Kreibich M, Dzilic E, Santer D, Forster L, Trojanek S, et al. Tenascin-C promotes chronic pressure overload-induced cardiac dysfunction, hypertrophy and myocardial fibrosis. J Hypertens (2018) 36:847-56. doi: 10.1097/HJH.0000000000001628

99. Nishioka T, Suzuki M, Onishi K, Takakura N, Inada H, Yoshida T, et al. Eplerenone attenuates myocardial fibrosis in the angiotensin II-induced hypertensive mouse: involvement of tenascin- $\mathrm{C}$ induced by aldosteronemediated inflammation. J Cardiovasc Pharmacol (2007) 49:261-8. doi: 10.1097/FJC.0b013e318033dfd4

100. Abbadi D, Laroumanie F, Bizou M, Pozzo J, Daviaud D, Delage C, et al. Local production of tenascin-C acts as a trigger for monocyte/macrophage recruitment that provokes cardiac dysfunction. Cardiovasc Res (2018) 114:123-37. doi: 10.1093/cvr/cvx221

101. Shimojo N, Hashizume R, Kanayama K, Hara M, Suzuki Y, Nishioka T, et al. Tenascin-C may accelerate cardiac fibrosis by activating macrophages via the integrin $\alpha \mathrm{V} \beta 3$ /nuclear factor- $\mathrm{\kappa B} /$ interleukin-6 axis. Hypertension (2015) 66:757-66. doi: 10.1161/hypertensionaha.115.06004

102. Song L, Wang L, Li F, Yukht A, Qin M, Ruther H, et al. Bone marrow-derived tenascin-C attenuates cardiac hypertrophy by controlling inflammation. J Am Coll Cardiol (2017) 70:1601-15. doi: 10.1016/j.jacc.2017.07.789

103. Park WJ, Jeong D, Oh JG. Tenascin-C in cardiac hypertrophy and fibrosis: friend or foe? J Am Coll Cardiol (2017) 70:1616-7. doi: 10.1016/ j.jacc.2017.08.014

104. Liu R, He Y, Li B, Liu J, Ren Y, Han W, et al. Tenascin-C produced by oxidized LDL-stimulated macrophages increases foam cell formation through Toll-like receptor-4. Mol Cells (2012) 34:35-41. doi: 10.1007/ s10059-012-0054-x

105. Wang L, Shah PK, Wang W, Song L, Yang M, Sharifi BG. Tenascin-C deficiency in Apo E-/- mouse increases eotaxin levels: implications for atherosclerosis. Atherosclerosis (2013) 227:267-74. doi: 10.1016/ j.atherosclerosis.2013.01.039

106. Wang L, Wang W, Shah PK, Song L, Yang M, Sharifi BG. Deletion of tenascin-C gene exacerbates atherosclerosis and induces intraplaque hemorrhage in Apo-E-deficient mice. Cardiovasc Pathol (2012) 21:398413. doi: 10.1016/j.carpath.2011.12.005

107. Hamada K, Miura Y, Toma N, Miyamoto K, Imanaka-Yoshida K, Matsushima S, et al. Gellan sulfate core platinum coil with tenascin-C promotes intra-aneurysmal organization in rats. Transl Stroke Res (2014) 5:595-603. doi: 10.1007/s12975-014-0352-z
108. Suzuki H, Kawakita F. Tenascin-C in aneurysmal subarachnoid hemorrhage: deleterious or protective? Neural Regener Res (2016) 11:230-1. doi: 10.4103/ 1673-5374.177721

109. Fujimoto M, Shiba M, Kawakita F, Liu L, Shimojo N, Imanaka-Yoshida K, et al. Effects of tenascin-C knockout on cerebral vasospasm after experimental subarachnoid hemorrhage in mice. Mol Neurobiol (2018) 55:1951-8. doi: 10.1007/s12035-017-0466-x

110. Shiba M, Suzuki H, Fujimoto M, Shimojo N, Imanaka-Yoshida K, Yoshida T, et al. Imatinib mesylate prevents cerebral vasospasm after subarachnoid hemorrhage via inhibiting tenascin-C expression in rats. Neurobiol Dis (2012) 46:172-9. doi: 10.1016/j.nbd.2012.01.005

111. Kimura T, Shiraishi K, Furusho A, Ito S, Hirakata S, Nishida N, et al. Tenascin C protects aorta from acute dissection in mice. Sci Rep (2014) 4:4051. doi: 10.1038/srep04051

112. Kimura T, Yoshimura K, Aoki H, Imanaka-Yoshida K, Yoshida T, Ikeda Y, et al. Tenascin-C is expressed in abdominal aortic aneurysm tissue with an active degradation process. Pathol Int (2011) 61:559-64. doi: 10.1111/j.14401827.2011.02699.x

113. Sato A, Aonuma K, Imanaka-Yoshida K, Yoshida T, Isobe M, Kawase D, et al. Serum tenascin-C might be a novel predictor of left ventricular remodeling and prognosis after acute myocardial infarction. J Am Coll Cardiol (2006) 47:2319-25. doi: 10.1016/j.jacc.2006.03.033

114. Morimoto S, Imanaka-Yoshida K, Hiramitsu S, Kato S, Ohtsuki M, Uemura A, et al. Diagnostic utility of tenascin-C for evaluation of the activity of human acute myocarditis. J Pathol (2005) 205:460-7. doi: 10.1002/path.1730

115. Tsukada B, Terasaki F, Shimomura H, Otsuka K, Otsuka K, Katashima T, et al. High prevalence of chronic myocarditis in dilated cardiomyopathy referred for left ventriculoplasty: expression of tenascin C as a possible marker for inflammation. Hum Pathol (2009) 40:1015-22. doi: 10.1016/ j.humpath.2008.12.017

116. Kitaoka H, Kubo T, Baba Y, Yamasaki N, Matsumura Y, Furuno T, et al. Serum tenascin-C levels as a prognostic biomarker of heart failure events in patients with hypertrophic cardiomyopathy. J Cardiol (2012) 59:209-14. doi: 10.1016/j.jjcc.2011.11.008

117. Terasaki F, Okamoto H, Onishi K, Sato A, Shimomura H, Tsukada B, et al. Higher serum tenascin-C levels reflect the severity of heart failure, left ventricular dysfunction and remodeling in patients with dilated cardiomyopathy. Circ J (2007) 71:327-30. doi: 10.1253/circj.71.327

118. Kanagala P, Arnold JR, Khan JN, Singh A, Gulsin GS, Chan DS, et al. Plasma Tenascin-C: a prognostic biomarker in heart failure with preserved ejection fraction. Biomarkers (2020) 25:556-65. doi: 10.1080/1354750X.2020.1810319

119. Hessel M, Steendijk P, den Adel B, Schutte C, van der Laarse A. Pressure overload-induced right ventricular failure is associated with re-expression of myocardial tenascin-C and elevated plasma tenascin-C levels. Cell Physiol Biochem (2009) 24:201-10. doi: 10.1159/000233246

120. Fujimoto N, Onishi K, Sato A, Terasaki F, Tsukada B, Nozato T, et al. Incremental prognostic values of serum tenascin-C levels with blood B-type natriuretic peptide testing at discharge in patients with dilated cardiomyopathy and decompensated heart failure. J Card Fail (2009) 15:898-905. doi: 10.1016/j.cardfail.2009.06.443

121. Hessel MH, Bleeker GB, Bax JJ, Henneman MM, den Adel B, Klok M, et al. Reverse ventricular remodelling after cardiac resynchronization therapy is associated with a reduction in serum tenascin- $\mathrm{C}$ and plasma matrix metalloproteinase-9 levels. Eur J Heart Fail (2007) 9:1058-63. doi: 10.1016/j.ejheart.2007.07.007

122. Okuma Y, Suda K, Nakaoka H, Katsube Y, Mitani Y, Yoshikane Y, et al. Serum tenascin- $\mathrm{C}$ as a novel predictor for risk of coronary artery lesion and resistance to intravenous immunoglobulin in Kawasaki disease- a multicenter retrospective study. Circ J (2016) 80:2376-81. doi: 10.1253/ circj.CJ-16-0563

123. Yokouchi Y, Oharaseki T, Enomoto Y, Sato W, Imanaka-Yoshida K, Takahashi K. Expression of tenascin C in cardiovascular lesions of Kawasaki disease. Cardiovasc Pathol (2019) 38:25-30. doi: 10.1016/ j.carpath.2018.10.005

124. Kul S, Ozcelik HK, Uyarel H, Karakus G, Guvenc TS, Yalcinsoy M, et al. Diagnostic value of strain echocardiography, galectin-3, and tenascin-C levels for the identification of patients with pulmonary and cardiac sarcoidosis. Lung (2014) 192:533-42. doi: 10.1007/s00408-014-9586-5 
125. Wallner K, Li C, Shah PK, Fishbein MC, Forrester JS, Kaul S, et al. Tenascin$\mathrm{C}$ is expressed in macrophage-rich human coronary atherosclerotic plaque. Circulation (1999) 99:1284-9. doi: 10.1161/01.cir.99.10.1284

126. Satta J, Soini Y, Pollanen R, Paakko P, Juvonen T. Tenascin expression is associated with a chronic inflammatory process in abdominal aortic aneurysms. J Vasc Surg (1997) 26:670-5. doi: 10.1016/s0741-5214(97) 70068-5

127. Gao W, Li J, Ni H, Shi H, Qi Z, Zhu S, et al. Tenascin C: a potential biomarker for predicting the severity of coronary atherosclerosis. J Atheroscler Thromb (2019) 26:31-8. doi: 10.5551/jat.42887

128. Guo T, Zhou X, Zhu A, Peng W, Zhong Y, Chai X. The role of serum tenascin- $\mathrm{C}$ in predicting in-hospital death in acute aortic dissection. Int Heart J (2019) 60:919-23. doi: 10.1536/ihj.18-462

129. Trescher K, Thometich B, Demyanets S, Kassal H, Sedivy R, Bittner R, et al. Type A dissection and chronic dilatation: tenascin-C as a key factor in destabilization of the aortic wall. Interact Cardiovasc Thorac Surg (2013) 17:365-70. doi: 10.1093/icvts/ivt204

130. Nozato T, Sato A, Hikita H, Takahashi A, Imanaka-Yoshida K, Yoshida T, et al. Impact of serum tenascin- $C$ on the aortic healing process during the chronic stage of type B acute aortic dissection. Int J Cardiol (2015) 191:97-9. doi: 10.1016/j.ijcard.2015.05.009

131. Suzuki H, Kanamaru K, Shiba M, Fujimoto M, Imanaka-Yoshida K, Yoshida $\mathrm{T}$, et al. Cerebrospinal fluid tenascin-C in cerebral vasospasm after aneurysmal subarachnoid hemorrhage. J Neurosurg Anesthesiol (2011) 23:310-7. doi: 10.1097/ANA.0b013e31822aalf2

132. Liabeuf S, Barreto DV, Kretschmer A, Barreto FC, Renard C, Andrejak M, et al. High circulating levels of large splice variants of tenascin-C is associated with mortality and cardiovascular disease in chronic kidney disease patients. Atherosclerosis (2011) 215:116-24. doi: 10.1016/j.atherosclerosis.2010.11.038

133. Gellen B, Thorin-Trescases N, Thorin E, Gand E, Sosner P, Brishoual S, et al. Serum tenascin- $\mathrm{C}$ is independently associated with increased major adverse cardiovascular events and death in individuals with type 2 diabetes: a French prospective cohort. Diabetologia (2020) 63:915-23. doi: 10.1007/s00125-02005108-5

134. Sato M, Toyozaki T, Odaka K, Uehara T, Arano Y, Hasegawa H, et al. Detection of experimental autoimmune myocarditis in rats by ${ }^{111} \mathrm{In}$ monoclonal antibody specific for tenascin-C. Circulation (2002) 106:1397402. doi: 10.1161/01.cir.0000027823.07104.86

135. Ageyama N, Kurosawa H, Fujimoto O, Uehara T, Hiroe M, Arano Y, et al. Successful inflammation imaging of non-human primate hearts using an antibody specific for tenascin-C. Int Heart J (2019) 60:151-8. doi: 10.1536/ ihj.17-734

136. Lipke DL, Aziz SM, Fagerland JA, Majesky M, Arcot SS. Tenascin synthesis, deposition, and isoforms in monocrotaline-induced pulmonary hypertensive rat lungs. Am J Physiol (1996) 271:L208-15. doi: 10.1152/ ajplung.1996.271.2.L208

137. Rohm I, Grun K, Muller LM, Kretzschmar D, Fritzenwanger M, Yilmaz A, et al. Increased serum levels of fetal tenascin-C variants in patients with pulmonary hypertension: novel biomarkers reflecting vascular remodeling and right ventricular dysfunction? Int J Mol Sci (2017) 18:2371-81. doi: $10.3390 /$ ijms 18112371

Conflict of Interest: The authors declare that the research was conducted in the absence of any commercial or financial relationships that could be constructed as a potential conflict of interest.

Copyright (C) 2020 Matsumoto and Aoki. This is an open-access article distributed under the terms of the Creative Commons Attribution License (CC BY). The use, distribution or reproduction in other forums is permitted, provided the original author(s) and the copyright owner(s) are credited and that the original publication in this journal is cited, in accordance with accepted academic practice. No use, distribution or reproduction is permitted which does not comply with these terms. 